\title{
Pola Asus Ibu Karir pada Anak di Masa Pandemi Covid-19 dalam Pendidikan Agama Islam di Desa Tlompakan, Kecamatan Tuntang, Kabupaten Semarang
}

\author{
Annisa Indah Nurina ${ }^{1}$, Naimatus Tsaniyah ${ }^{2}$ \\ ${ }^{1}$ Program Studi Pascasarjana, Fakultas Keguruan dan Ilmu Pendidikan, IAIN Salatiga \\ nikmahtsaniyah22@gmail.com ${ }^{1}$ \\ ${ }^{2}$ Program Studi Pascasarjana, UIN Sunan Kalijaga Yogyakarta \\ annisahangkara@gmail.com $^{2}$
}

\begin{abstract}
Abstrak
Penelitian ini bertujuan untuk mengetahui pola asuh yang dilakukan oleh ibu karir dalam pendidikan Islam pada anak dimasa pandemi Covid-19 di Desa Tlompakan, Kecamatan Tuntang, Kabupaten Semarang Tahun 2020. Penelitian ini adalah penelitian lapangan yang menggunakan pendekatan kualitatif. Subjek penelitian ini adalah ibu karier. Data dalam penelitian ini diperoleh melalui observasi, wawancara, dan dokumentasi. Hasil penelitian ini menunjukkan bahwa kebanyakan ibu yang berkarier di Desa Tlompakan, Kecamatan Tuntang, Kabupaten Semarang Tahun 2020 pada masa pandemi Covid-19 mempunyai karakteristik, yaitu (1) membuat jadwal belajar; (2) komunikasi; (3) jam sekolah yang dilakukan dirumah dan pendidikan agama lebih banyak; serta (4) membagi peran mengasuh. Lebih lanjut, para ibu karier memasukan ajaran agama Islam sejak dalam kandungan. Penanaman pendidikan agama yang kuat, berakhlak, dan pandai dalam membaca Al-Quran adalah efek dari pola asuh orang tua yang dipupuk sejak kecil. Pola asuh yang demokrasi pula mampu mengembangkan anak-anak dari segi: (1) perkembangan fisik yang kuat agar tidak menjadi muslim yang pemalas; (2) perkembangan kognitif yang baik agar menjadi muslim yang cerdas dalam intelektualitasnya; dan (3) perkembangan sosial agar menjadi manusia yang baik menjalin dengan makhluk-makhluk Allah secara bijaksana. Adapun faktor pendukung dan penghambat pola asuh ibu karir di Desa Tlompakan pada masa pandemi Covid-19 dalam pendidikan Agama Islam yang utama berkaitan dengan latar belakang ibu karier, kondisi pandemi, dan lingkungan sekitar.
\end{abstract}

Kata Kunci: Pola Asuh Anak; Ibu Karier; Pendidikan Agama Islam; Covid-19.

\section{PENDAHULUAN}

Covid-19 melanda banyak negara di dunia termasuk Indonesia. Wabah Covid-19 tidak hanya merupakan masalah nasional dalam suatu negara, tapi sudah merupakan masalah global. Covid-19 berawal muncul dari daerah Wuhan, Cina. Penyebaran Covid-19 yang begitu cepat dan mematikan, penularannya melalui kontak fisik ditularkan melalui mulut, 
mata dan hidung. Covid-19 berdampak kepada kehidupan sosial dan melemahnya ekonomi masyarakat. Permasalahan bagaimana dampak wabah Covid-19 terhadap pelayanan publik dan upaya penanggulangan wabah Covid-19. Dampak wabah Covid-19 menimbulkan masalah sosial pelemahan ekonomi masyarakat dan negara, untuk mencegah penyebaran wabah Covid-19 diperlukan kerja sama pemerintah, masyarakat, tokoh agama untuk saling bantu membatu, bahu membahu dan mengingatkan satu sama lainnya bersama melawan Covid-19.

Kasus-kasus yang ditemukan saat ini, dampak Covid-19 memiliki angka kematian yang terus meningkat. Hingga saat ini WHO belum memberlakukan travel restriction (pada saat penelitian ini dilakukan). Namun demikian tetap harus diwaspadai karena sumber penularan dan perkembangan virus ini masih belum jelas. Pandemi adalah penyakit yang menyebar secara global meliputi area geografis yang luas. Pada masa pandemi Covid-19 ini semua anak harus belajar dari rumah untuk mencegah penularan virus Corona atau Covid19, sistem pendidikan berbasis online pun digalakkan. Di samping disiplin pribadi untuk belajar secara mandiri, ada fasilitas dan sumber daya yang mesti disediakan. Kehadiran orang tua sangat dibutuhkan untukmendampingi anak belajar dari rumah. Orang tua harus menjelaskan berbagai mata pelajaran kususnya pendidikan agama Islam dalam bidang baca tulis Al-Qur'an dan akhlaq karena TPQ, Madrasah Diniyah terpaksa diliburkan. Hampir tidak ada yang menyangka, wajah pendidikan akan berubah drastis akibat pandemi Covid19. Kebijakan physical distancing untuk memutus penyebaran wabah, memaksa perubahan dari pendidikan formal di bangku sekolah menjadi belajar dari rumah, dengan sistem online, dalam skala nasional yang sebenarnya justru lebih sulit.

Orang tua terutama ibu pada masa pandemi ini dituntut untuk lebih banyak waktu menemani belajar anak, ikut andil dalam pekerjaan sekolah anak, tapi juga harus tetap bertahan dalam karir atau pekerjaannya karena semasa Covid-19 ini kebutuhan semakin bertambah dan lapangan pekerjaan semakin sedikit. Keluarga merupakan pranata terkecil serta utama dalam kehidupan manusia. Semua berawal dari keluarga, belajar, makan, minum, berjalan dan berbicara. Manusia pun mempersiapkan diri untuk menghadapi dunia luar. Pembentukan jati diri pun bermula pada suatu keluarga. Oleh karena itu baik buruknya struktur keluarga dan masyarakat memberikan pengaruh baik atau buruknya pertumbuhan kepribadian anak (Kartono 2007, hlm. 57).

Anak akan berkembang dengan tepat baik secara kognitif dan efektif dengan adanya interaksi yang baik antara ibu dan anak. Hal ini membenarkan bagaimana peran ibu sangatlah penting dalam keluarga untuk tumbuh kembang anak. Setiap anak memiliki perasaan nyaman dan mempunyai kedekatan dengan salah satu orang tua, yaitu kepada ayah atau ibu (Putri 2013, hlm.176-188). Orang tua atau ayah dan ibu memegang peran penting dan amat berpengaruh atas pendidikan anak-anaknya. Sejak seorang anak lahir, ibunyalah yang selalu disampingnya. Oleh karena itu, anak meniru perangai ibunya dan kebiasaannya, seorang anak lebih cinta kepada ibunya, apabila ibu itu menjalankan tugasnya dengan baik (Drajat 1994, hlm. 35). 
Dari pernyataan diatas, ibu adalah sosok yang sangat penting yang bertanggung jawab penuh terhadap pendidikan anak di dalam keluarga. Oleh sebab itu, ibu mendapat julukan sebagai итти al-madrasatul yang berarti ibu merupakan sekolah pertama bagi anakanaknya. Maksud dari istilah tersebut adalah ibu sebagai fasilitator pertama dan utama dalam mendidik anak-anaknya sebelum masuk ke lembaga pendidikan formal, seperti sekolah maupun TPA. Peran orang tua sangat penting terutama peran ibu, tetapi karena kebutuhan banyak ibu-ibu karir atau bekerja yang menyita waktu hampir setengah hari dan ada yang lebih.

Pendidikan Agama Islam mempunyai peranan yang besar terhadap perkembangan anak, baik pada usia anak saat itu maupun pada usia selanjutnya. Internalisasi nilai-nilai keagamaan dan kemanusiaan yang berlangsung sejak usia dini mampu membentuk kepribadian dan karakter anak, sehingga mempunyai pengaruh yang kuat sepanjang hidup. Anak-anak adalah generasi yang akan menentukan nasib bangsa di kemudian hari. Perilaku orang dewasa merupakan hasil dari pendidikan di waktu kecil. Jika di masa kecilnya mendapatkan pendidikan yang tepat, anak-anak akan tumbuh menjadi orang dewasa yang berkarakter, disiplin, bertanggung jawab, bijaksana, berpikir jauh kedepan dan lain sebagainya.

Pendidikan sangatlah penting bagi kehidupan di dunia ini. Pada hakikatnya pendidikan merupakan proses budaya untuk meningkatkan harkat dan martabat manusia. Maka dari itu, seseorang harus mempunyai suatu pengetahuan, yang mana pengetahuan tersebut merupakan perlengkapan dasar manusia didalam menempuh kehidupan ini. Ternyata hal yang terpenting pada kehidupan manusia itu sangat dipengaruhi oleh kualitas dan kuantitas suatu pengetahuan yang diperolehnya. Dengan begitu kepribadian setiap manusia akan berbeda, dan itupun sesuai dengan kualitas dan kuantitas yang diperolehnya. Kesensitifan remaja membutuhkan bimbingan dalam kehidupannya untuk menemukan jati dirinya. Kebutuhan dan pengajaran utama akan didapatkan dalam keluarga (Santrock 2007, hlm. 36).

Meskipun ada beberapa kondisi yang menyebabkan anak tidak bisa mendapatkan pendidikan dari orang tuanya, seperti anak yatim piatu semenjak lahir, anak yang dibuang oleh orang tuanya, dan sebagainya. Tetapi dalam kondisi normal, orang tua merupakan pendidik anak yang pertama dan utama. Bahkan dalam Al-Quran serta Sunnah banyak sekali ditegaskan tentang pentingnya mendidik anak bagi para orang tua. Anak yang terdidik dengan baik oleh orang tuanya akan tumbuh lebih baik, menjadi anak yang pandai menjaga dirinya dari pengaruh buruk lingkungan, karena ia telah dibekali oleh ilmu tentang hidup dan kehidupan yang didalamnya terdapat ilmu yang paling bermanfaat yaitu ilmu agama.

Pendidikan akan menghasilkan kualitas manusia yang memiliki kehalusan budi dan jiwa, memiliki kecemerlangan pikir, kecekatan raga, dan memiliki kesadaran penciptaan diri. Perkembangan dan pertumbuhan emansipasi telah membawa kaum wanita berpacu dengan kaum laki-laki. Kaum wanita telah dapat menjamah dan menjangkau berbagai profesi dan keahlian dari berbagai cabang ilmu pengetahuan dan teknologi. Di lapangan kerja wanita mempunyai banyak lowongan sehingga bebas memilih memilih sesuai 
kemampuan. Semuanya akan berakibat langsung kepada pembinaan keluarga dan rumah tangga (Leter, 1985, hlm. 86). Seorang ibu adalah manusia yang dilengkapi dengan kebaikan sifat dan keindahan kepribadian. Para sahabat perempuan Rasulullah SAW. repot sekali dengan pekerjaan rumahnya yang sulit kita bayangkan (Sufyan, 2007, hlm. 50) .

Ibu karir memiliki ambiguitas tinggi antara pekerjaannya dengan perannya sebagai ibu rumah tangga. Namun, konflik peran dapat dikurangi jika melibatkan pekerja (wanita karir) untuk berpartisipasi dalam menyusun anggaran (Siwi, 2005, hlm.7). Konsepsi kesejajaran antara pria dan wanita di Indonesia telah ada dan dilakukan sejak zaman dahulu. Misalnya, Ratu Sima yang dikenal sebagai raja yang adil, yang tidak segan menghukum siapa saja tanpa pandang bulu. Tribuana Tungga Dewi Jayawisnuwardhani tercatat pula sebagai ratu yang menggantikan kakaknya Jayanegara pada zaman Majapahit. Di zaman penjajahan, muncul para pejuang wanita, seperti Cut Nyak Dien, Kristina Martha Tiahahu dan sebagainya. Para tokoh perempuan tersebut berjuang dengan gigih dalam memperebutkan kemerdekaan Republik Indonesia. Pada zaman pembangunan sekarang ini, sering ditemui seorang pria yang bekerja sebagai tukang masak, bekerja di salon kecantikan, penjahit, yang sebenarnya pekerjaan itu umumnya dilakukan oleh wanita, begitupun sebaliknya, banyak wanita bekerja dibidang proyek pembangunan, sebagai mandor, manager, dan harus tetap melaksanakan tugas sebagai ibu dan istri, bertanggung jawab atas pendidikan anak terutama pendidikan Agama Islam.

\section{METODE PENELITIAN}

Penelitian ini menggunakan data lapangan (field reseach) dengan pendekatan etnografi. Penelitian ini termasuk penelitian kualitatif. Dalam pengumpulan data, peneliti menggunakan teknik wawancara, observasi, dan dokumentasi. Objek dalam penelitian ini adalah wanita karir yang sudah mempunyai anak (ibu karir). Observasi untuk mendapatkan gambaran Pendidikan Agama Islam bagi anak-anak dalam lingkup keluarga pekerja (studi analisis keluarga komunitas ibu karir di Dusun Semen, Desa Tlompakan, Kecamatan Tuntang, Kabupaten Semarang). Analisis data kualitatif dilakukan secara interaktif dan berlangsung terus menerus sampai tuntas. Digunakan pula 19 model analisis yang terdiri dari tiga komponen yaitu reduksi data, penyajian data, dan penarikan kesimpulan dengan melakukan verifikasi kepada ibu karir Desa Tlompakan.

\section{HASIL DAN PEMBAHASAN}

\section{Perbedaan Pola Asuh Semasa Pandemi Covid-19 dan Sebelum Covid-19 Pola Asuh Sebelum Pandemi Covid-19}

Kegiatan sebelum pandemi Covid-19 kegiatan yang dilakukan di rumah setiap hari, misalnya membaca iqro atau Al-Quran setiap ba'da magrib dilakukan di Mesjid bersama ustadz dan teman-temanya, pendidikan formal dilakukan di sekolahan. Kegiatan terprogram yang dilakukan secara rutin, seperti membersihkan tempat tidur setiap pagi, memiliki jadwal tetap belajar dirumah. Sebelum pandemi Covid-19 ibu karier yaitu ZBD merasa lebih tenang 
karena anak bisa bebas berekspresi. Manajemen waktu memang hal yang terhitung berat bagi ibu karier. Ketika membutuhkan tidak ada disetiap saat, CAL ketika deadline tugas kerja sudah dekat dan masih belum selesai, CAL mengesampingkan tugas rumah. Setelah selesai tugas kerja, baru kemudian meneruskan tugas rumah. CAL memberikan pembiasaan jam belajar kepada putrinya yang terjadwal setiap harinya. Semua merupakan tugasnya sebagai ibu dan wanita karir. Di samping itu, kritikan dan celaan dianggap biasa oleh CAL apalagi seorang janda. Dari proses itu, CAL belajar mengatasi rintangan, berpengalaman, termotivasi, tambah sabar, dan menguatkan diri diiringi (Wawancara dengan CAL pada tanggal 17 Juli 2020).

\section{Pola Asuh Semasa Pandemi Covid-19}

Setiap orang tua umumnya pada menginginkan anak yang pandai dibidang pengetahuan dan agama. Seringkali rintangan, tantangan, maupun kesulitan dihadapkan pada seseorang dalam proses untuk mencapainya. Oleh karena itu, perlu pembiasaan diri untuk dapat menghadapi kesulitan tersebut. Seperti dimasa pandemi ini termasuk masa yang cukup sulit bagi orang tua, guru, dan terutama anak. Anak yang seharusnya lebih banyak bimbingan diharuskan belajar di rumah dibimbing orang tua, tapi banyak sekali orang tuanya yang sibuk bekerja (jarang berada di rumah). Hal ini disebabkan oleh tuntutan pekerjaan orang tua terutama ibu belum bisa memberikan waktu yang banyak untuk menemani, membimbing, mengajari anak-anak.

Pendidikan dengan pembiasaan merupakan suatu metode yang sangat efektif untuk diterapkan pada anak usia Sekolah Dasar. Karena pada masa ini merupakan masa keemasan anak, dimana anak mengalami pertumbuhan dan perkembangan yang sangat pesat. Anak kadang hilang semangat karena karir atau pekerjaan ibu, intensitas dalam bertemu juga mempengaruhi motivasi belajar anak. Menurut ZBD, untuk membimbing anak dalam berperilaku, dan belajar mengaji bukan hal yang mudah. Pasti akan berhadapan dengan rintangan, tantangan, maupun kesulitan dihadapkan pada seseorang dalam proses. Oleh karena itu, perlu pembiasaan untuk dapat menghadapi kesulitan. Maka pembelajaran tentang akhlak dan baca tulis Al-Quran, serta cara-cara menghadapi kesulitan harus dibangun dari hal itu. Akan tetapi, pembiasaan tidak dapat dibangun dengan instan, melainkan bergantung pada pengalaman yang diperoleh. Pada proses itu, seseorang berhadapan dengan persoalan, sehingga mampu berpikir untuk menyikapinya, karena sesungguhnya orang yang hidup pasti berhadapan dengan persoalan (Wawancara dengan ZBD pada tanggal 25 Mei 2019).

MF mengatakan bahwa dirinya terbiasa mengaji setiap ba'da maghrib dan selalu diberikan pengertian tentang fiqih, aqidah akhlak, bahasa Arab setelah belajar baca tulis AlQuran karena dari umur 3 tahun sudah dituntun orang tua terutama ibu untuk meluangkan waktu setiap harinya, yaitu ba'da mahrib untuk mengaji, walaupun lebih sering ditemani ayahnya. Tapi ibunya selalu menanyakan: 1) sudah ngaji atau belum?; 2) sudah juz berapa?; dan sebagainya. Setiap sebelum tidur pun, kalau bisa pulang lebih awal ibu ikut andil dalam mengajar ngaji (Wawancara dengan MF pada tanggal 25 Mei 2019). 
Narasumber lain, NS, meskipun jauh dari ibunya tapi dari kecil sebelum ibunya berangkat ke Negara lain sampai sekarang walaupun lewat handphone dia sudah dibiasakan untuk selalu hormat kepada orang tua, dan izin sebelum keluar rumah kemanapun dan dimanapun. Setiap harinya NS menemani dan membantu neneknya membersihkan rumah dengan senang hati. Setelah maghrib NS mengaji yang biasanya di Mesjid, tetapi karena pandemi NS melakukannya di rumah bersama nenek, shalat juga selalu dilakukan tepat waktu. Pada masa pandemi ini semua dilakukan dirumah, NS lebih sering merasa sangat rindu, ingin sekali ada ibunya dirumah untuk shalat bersama, makan bersama, bermain bersama, mengaji bersama karena banyaknya waktu kosong jadi NS sering berandai-andai tentang ibunya, biasanya mengaji, belajar ia lakukan bersama teman-teman jadi kadang lupa tentang kesedihan jauh dari ibunya (Wawancara dengan NS pada tanggal 20 Juli 2020).

Menurut SW kesulitan harus diselesaikan agar tidak berlarut-larut. Jadi kesulitan itu harus diatasi supaya bisa lebih tenang dalam memberikan ilmu. SW sempat mengambil langkah ingin keluar dari pekerjaan karena ingin memanfaatkan waktu yang lebih untuk anaknya, bisa mengontrol secara langsung kegiatan anak-anaknya yang masih Sekolah Dasar, karena menurut SW seumuran anaknya rasa ingin tahunya sangat lebih terhadap apapun, jadi kalau bisa ditanamkan dengan hal-hal positif. Tapi karena ekonomi keluarga, SW mengurungkan niatnya untuk keluar dari pekerjaan. Walaupun begitu SW mempunyai cara untuk mendidik anaknya, yaitu dengan membiasakan berbahasa baik dan benar dimulai dari rumah, belajar aqidah akhlak dan fiqih disesuaikan kejadian pada setiap harinya tanpa ada ikatan waktu. Terkait belajar baca tulis Al-Quran pada anak-anaknya, SW sudah membiasakan dengan menjadwalkan kusus untuk mengaji, meski tidak bisa langsung dalam hal mendidik, pulang kerja sebelum tidur SW selalu memberikan pertanyaan tentang kegiatan harian anak-anaknya yang didasari rasa ingin tahu SW dan sebagai bentuk perhatiannya (Wawancara dengan SW pada tanggal 25 Mei 2019).

Ibu karir harus memperhatikan pembiasaan yang diterapkan untuk anak-anaknya. Misalnya memberikan motivasi, nasihat, aturan, dan selalu mengontrol lewat media sosial. Pembiasaan merupakan kegiatan yang dilakukan secara teratur dan berkesinambungan untuk melatih anak agar memiliki kebiasaan-kebiasaan tertentu. Umumnya berhubungan dengan pengembangan kepribadian anak seperti emosi, disiplin, budi pekerti, kemandirian, penyesuaian diri, hidup bermasyarakat, dan lain sebagainya. Orang tua adalah pembina pribadi yang utama dalam hidup anak, kepribadian orang tua, sikap dan cara hidup orang tua merupakan unsur-unsur pendidikan yang tidak berlangsung dengan sendirinya akan masuk ke dalam pribadi anak yang sedang tumbuh ( Darajat, 2005, hlm. 73).

Adapun bentuk-bentuk pembiasaan pada anak dapat dilaksanakan dengan cara berikut.

1. Kegiatan rutin, adalah kegiatan yang dilakukan di rumah setiap hari, misalnya membaca Iqro atau Al-Quran setiap ba'da magrib, berdoa sebelum dan sesudah melakukan kegiatan.

2. Kegiatan spontan adalah kegiatan yang dilakukan secara spontan, misalnya meminta tolong dengan baik, menawarkan bantuan dengan baik, menanyakan kegiatan hari ini. 
3. Pemberian teladan adalah kegiatan yang dilakukan dengan memberi teladan/contoh yang baik kepada anak, misalnya membuang sampah pada tempatnya dan sopan dalam bertutur kata.

4. Kegiatan terprogram adalah kegiatan yang dilakukan secara rutin, seperti membersihkan tempat tidur setiap pagi, memiliki jadwal tetap belajar di rumah.

Upaya untuk memelihara kebiasaan yang baik pada anak adalah sebagai berikut.

1. Melatih hingga benar-benar paham dan bisa melakukan tanpa kesulitan. Sesuatu hal yang baru tentu tidak mudah dilakukan semua anak, maka pembiasaan bagi anak perlu dilakukan sampai anak dapat melakukannya. Pendidik perlu membimbing dan mengarahkan agar anak-anak mampu melakukan khususnya baca tulis Al-Quran dan akhlak.

2. Mengingatkan anak yang lupa melakukan kegiatan positif. Anak-anak perlu diingatkan dengan ramah jika lupa atau dengan sengaja tidak melakukan kebiasaan positif yang telah diajarkan tapi jangan sampai mempermalukan anak. Teguran sebaiknya dilakukan secara pribadi.

3. Apresiasi pada masing-masing anak secara pribadi. Pemberian apresiasi dapat membuat anak senang, tetapi harus hati-hati jangan berlebihan.

4. Hindarkan mencela pada anak. Seluruh perilaku dalam mendidik anak diupayakan agar menguntungkan bagi perkembangan anak dengan tidak mencela anak, walau terdapat kesalahan atau kekurangan padanya.

Pembiasaan di sini adalah pembentukan keterampilan berucap, berbuat sesuai dengan yang diajarkan agama. Pembiasaan ini mempunyai arti yang penting karena merupakan sarana paling efektif guna pembentukan pribadi yang shaleh. Lagi pula pada masa usia dini anak cenderung bersifat imitatif atau suka meniru apa yang dilihat dan diketahui. Dengan demikian, ketika yang dilihat dan diketahui oleh anak itu adalah hal-hal yang baik dan dibiasakan sejak dini, maka akan sangat efektif bagi pembentukan pribadi yang baik. Pembiasaan merupakan upaya yang dilakukan untuk mengembangkan perilaku anak, yang meliputi perilaku keagamaan, sosial, emosional dan kemandirian. Pembiasaan merupakan proses penanaman kebiasaan. Kebiasaan adalah pola untuk melakukan tanggapan terhadap situasi tertentu yang dipelajari oleh seorang individu dan yang dilakukan secara berulangulang untuk hal yang sama. Pembiasaan adalah sesuatu yang sengaja dilakukan secara berulang-ulang agar sesuatu itu dapat menjadi kebiasaan. Pendidikan Agama Islam sebagai pendidikan nilai maka perlu adanya pembiasaan-pembiasaan dalam menjalankan ajaran Islam, sehingga nilai-nilai ajaran Islam dapat terinternalisasi dalam diri peserta didik, yang akhirnya akan dapat membentuk karakter yang Islami.

Jadi, pola asuh dimasa pandemi ini lebih sulit dilaksanakan ibu karir yang sebagian besar bermasalah dengan waktu. Pola asuh sebelum pandemi Covid-19 anak dapat melakukan pembelajaran di luar rumah dan kegiatan lainnya, sedangkan semasa pandemi Covid-19 harus mengawasi anak dengan ketat. Ibu karir dalam pendidikan agama Islam 
dibidang akhlaq dan baca tulis Al-Quran anak usia Sekolah Dasar pada masa pandemi Covid-19 di Desa Tlompakan, bahwa pembiasaan merupakan upaya yang dilakukan untuk mengembangkan perilaku anak, yang meliputi perilaku keagamaan, sosial, emosional dan kemandirian.

\section{SIMPULAN}

Pola asuh ibu karir dalam pendidikan agama Islam pada anak semasa pandemi Covid19 di Desa Tlompakan, yakni ibu karir melakukan pola asuh yang demokratis. Pola asuh demokratis tersebut diantaranya, ibu karir memberikan jadwal harian pada anak, dan memberikan ruang anak untuk bercerita, bertanya dengan diawali menanyakan kegiatan anak saat tidak bersamanya. Lalu, dilanjutkan dengan menanyakan kesulitan yang dialami, dan terakhir mengevaluasi. Dengan pola asuh demokratis menjadikan anak mandiri, mempunyai kontrol diri dan kepercayaan diri yang kuat, dapat berinteraksi dengan teman sebayanya dengan baik, mampu menghadapi stres, mempunyai minat terhadap hal-hal yang baru, kooperatif dengan orang dewasa, penurut, patuh dan berorientasi pada prestasi.

Ada beberapa karakteristik orang tua karir ganda terhadap anak dalam pendidikan agama Islam dimasa pandemi Covid-19, yaitu: 1) membagi jam pengasuhan, artinya para orang tua bergantian mengasuh anaknya jika ada waktu yang kosong dalam bekerja atau beraktifitas di luar rumah; 2) komunikasi, dengan komunikasi yang baik maka pola asuh yang dibangun akan kuat dan tidak ada salah komunikasi tentang penerapan yang direalisasikan kepada anak dalam pendidikan agama Islam; 3) memilih lingkungan yang baik, karena jika lingkungan baik maka para orangtua merasakan keamanan untuk anak-anaknya dalam bersosialisasi kepada teman-temannya. Adapun pola asuh ibu karir semasa pandemi Covid19 dibanding sebeum Covid-19 memiliki perbedaan di Desa Tlompakan, antara lain 1) waktu, karena semua dilakukan dari rumah secara virtual, maka anak sangat butuh orang tuanya, peran ibu sebagai teman dan penyemangat, maka ibu karir harus pintar-pintar membagi waktu; dan 2) tempat belajar, semua kegiatan pembelajaran yang tadinya dilakukan di Sekolah, Madrasah, dan Mesjid, harus diganti dengan di rumah saja.

\section{DAFTAR PUSTAKA}

Fadillah, Ika dkk. (2010). Hubungan Tipe Pola Asuh Orang Tua dengan Emotional Quotient pada Anak Usia Prasekolah di TK Islam AlFatihah Sumampir Purwokwrto Utara. Jurnal Keperawatan Soedirman (The Soedirman Journal of Nursing), 1(1), hlm 2032.

Fara, Raissa, Putri.(2013). Pola Pengasuhan Oleh Polisi Wanita (Studi Deskriptif Mengenai Pola Asuh Anak Oleh Polisi Wanita). Surabaya: Tidak Diterbitkan.

Kartono, Kartini. (2007). Penerapan Keluarga Memandu Anak. Jakarta: Rajawali.

Leter. (1985). Tuntunan Rumah Tangga Muslim dan Keluarga Berencana. Padang: Angkasa Raya. 
Santrock, John W. (2007). Psikologi Pendidikan (Edisi Kedua). Jakarta: Kencana Prenada Media Group.

Tri, Siwi. (2005). Simposium Riset Ekonomi Pengaruh Komitmen Profesi, Partisipasi Anggaran dan Self-Efficacy terhadap Konflik Peran. Yogyakarta: Studi Empiris Pada Wanita Karir.

Ummu, Sufyan. (2007). Senarai Konflik Rumah Tangga. Bandung: PT Remaja Rosdakarya.

Zakiyah, Dradjat. (1994). Pendidikan Islam dalam Keluarga dan Sekolah. Jakarta: Ruhama.

Zakiyah, Darajat. (2005). Ilmu Jiwa Agama. Jakarta: Bulan Bintang. 
88 | Nurina \& Tsaniyah - Pola Asuh Ibu Karir ... 